\title{
Validation of the Cullender and Smith Method for Determining Pressure Loss in the Tubing of Gas Wells
}

\author{
Muhammad Zakiy Yusrizal ${ }^{1 *}$, Anas Puji Santoso ${ }^{1)}$ \\ ${ }^{1)}$ Petroleum Engineering, Universitas Pembangunan Nasional Veteran Yogyakarta \\ *corresponding e-mail: muhammadzakiy@upnyk.ac.id
}

\begin{abstract}
The ability of the reservoir to deliver a certain quantity of gas depends both on the inflow performance relationship and the flowing bottom hole pressure. In order to determine the deliverability of the total well system, it is necessary to calculate all the parameters and pressure drops, one of which in the tubing. Calculation of pressure loss in the tubing is a very important parameter in the stability of fluid flow from the reservoir to the surface. The calculation of pressure loss in the tubing which is most widely used in the field is the Cullender and Smith Method. The purpose of this study is to validate why the Cullender and Smith method is most widely used in the field to determine the pressure loss in the tubing compared to other pressure loss in tubing methods.

The methodology used in this study is calculating the pressure loss in the tubing with the Average Temperature and Deviation Factor Method, the Sukkar and Cornel Method, and the Cullender and Smith Method. After calculating the pressure loss in the tubing using each of these methods, then comparing the percent error of the calculation method with the results in the well. The data used in the calculation is the data from the MZ Field from 7 wells in the East Kalimantan area.

The results of the average error percentage obtained from this study are the Average and Deviation Factor Method is $5.38 \%$, the Sukkar and Cornell Method is 5.65\%, and the Cullender and Smith Method is $3.83 \%$. From this study, it can be said that the Cullender and Smith Method to be valid or the most accurate method for used in the field compared to other methods due to resulting the smallest percent error from the calculation.
\end{abstract}

Keywords: gas wells; pressure loss; pressure loss in the tubing

\section{INTRODUCTION}

The ability of the reservoir to deliver a certain quantity of gas depends both on the inflow performance relationship and the flowing bottom hole pressure. In order to determine the deliverability of the total well system, it is necessary to calculate all the parameters and pressure drops, one of which in the tubing. The method used in determining the pressure loss in the tubing can be determined in several ways. The selection of these methods is adjusted to the conditions of the production wells, especially gas production wells in this study.

In this study field which consists of 7 (seven) wells, the calculation of the pressure loss will be presented only using the Cullender and Smith Method. This method is a method that is most widely used in the field for the calculation of determining the pressure loss in the tubing. So that the purpose of this study is to validate why the Cullender and Smith method is most widely used in the field to determine the pressure loss in the tubing compared to other pressure loss in tubing methods.

The approach used in determining the pressure loss in the tubing in gas wells is based on the concept of the Law of Conservation of Energy. The calculation method used is to calculate the pressure loss using the Average Temperature and Deviation Factor Method, Sukkar and Cornel Method, and Cullender and Smith Method. After performing calculations with each of these methods, a comparison of the flowing bottom hole pressure calculated from each method will be carried out with the flowing bottom hole pressure measured in the field.

Calculation of pressure loss in the tubing is a very important parameter in the stability of fluid flow from the reservoir to the surface. It is important to calculate the pressure loss in the tubing using the right calculation method. The calculation of pressure loss in the tubing which is most widely used in the field is the Cullender and Smith Method. This study will validate whether the Cullender and Smith Method is the most accurate method or is the method with the smallest percent error when compared to other pressure loss calculation methods. 
The approach used in determining the pressure loss in the tubing based on the General Flow Equations. These general flow equations, based on the mechanical energy balance, contain no assumptions regarding temperature and can be used with either straight line or curved temperature gradients. Although these general flow equations are solved by numerical means, the methods are as convenient as many of those used today to calculate pressures in gas wells and pipelines. These numerical methods are illustrated for flowing and static columns of gas in wells and for flow in pipelines. The friction factors recommended in this study are based on an absolute roughness of 0.0006 in.

\section{METHODS}

The methodology used in this study is calculating the pressure loss in the tubing with the Average Temperature and Deviation Factor Method, the Sukkar and Cornel Method, and the Cullender and Smith Method (shown in flowchart Figure 1). After calculating the pressure loss in the tubing using each of these methods, then comparing the percent error of the calculation method with the results in the well. The data used in the calculation is the data from the MZ Field in the East Kalimantan area.

The following are step by step for calculating the pressure loss in the tubing using the Average Temperature and Deviation Factor Method:

1. Assume the $\mathrm{P}_{\mathrm{wf}}$.

2. Calculate average pressure $(\overline{\mathrm{P}})$, psia, where $\bar{P}=\frac{\left(P_{w f}+P_{t f}\right)}{2}$ and average temperature $(\overline{\mathrm{T}}),{ }^{\circ} \mathrm{R}$, where $\bar{T}=\frac{\left(T_{w f}+T_{t f}\right)}{2}$

3. Calculate pseudo critical pressure $\left(\mathrm{P}_{\mathrm{pc}}\right)$, where $P_{p c}=709.6-58.7 \gamma_{g}$ for natural gas.

4. Calculate pseudo reduce pressure $\left(\mathrm{P}_{\mathrm{pr}}\right)$, where $P_{p r}=\frac{\bar{P}}{P_{p c}}$

5. Calculate pseudo critical temperature $\left(\mathrm{T}_{\mathrm{pc}}\right)$, where $T_{p c}=170.5+307.3 \gamma_{\mathrm{g}}$ for natural gas.

6. Calculate pseudo reduce temperature $\left(\mathrm{T}_{\mathrm{pr}}\right)$, where $T_{p r}=\frac{\bar{T}}{T_{p c}}$

7. Calculate gas deviation factor $(\overline{\mathrm{z}})$, is a function of $\mathrm{P}_{\mathrm{pr}}$ and $\mathrm{T}_{\mathrm{pr}}$.

8. Calculate average gas viscosity $\left(\bar{\mu}_{\mathrm{g}}\right)$, cp. Using Lee Correlation.

9. Calculate Reynold Number $\left(\mathrm{N}_{\mathrm{Re}}\right)$, where $N_{R e}=20011 \frac{q(M M s c f d) \gamma}{\mu(c p) D(i n)}$ and calculate $\frac{\mathrm{e}}{\mathrm{D}}$.

10. Calculate Moody friction factor $(\overline{\mathrm{f}})$, is a function of $\mathrm{N}_{\mathrm{Re}}$ and $\frac{\mathrm{e}}{\mathrm{D}}$. Obtained from Moody graph or using Nikuradse Correlation or Jain Correlation.

11. Calculate length of flow string or tubing $(\mathrm{L}), \mathrm{ft}$, where $L=\frac{H}{\cos \theta}$ For vertical well, $\mathrm{L}=\mathrm{H}$ or $\mathrm{Z}$

12. Calculate $\mathrm{P}_{\mathrm{wf}}$ using equation $P_{w f}^{2}=P_{t f}^{2} e^{s}+\frac{25 \gamma_{g} \bar{T} \bar{z} \bar{f} L\left(e^{s}-1\right) q^{2}}{s D^{5}}$ where $\mathrm{P}_{\mathrm{tf}}$ is flowing well head pressure, psia, $s=\frac{2 \gamma_{\mathrm{g}} Z}{53.34 \bar{T} \bar{Z}} \quad$ (10), and $\mathrm{Z}$ is vertical distance of reservoir from surface, $\mathrm{ft}$.

13. Comparing the assumed $P_{w f}$ with the calculated $P_{w f}$, if $A b s=\left(\frac{\text { Assumed } P_{w f}-\text { Calculated } P_{w f}}{P_{w f}}\right) \leq$ tolerance, then the calculation is complete, where $\mathrm{P}_{\mathrm{wf}}=\mathrm{P}_{\mathrm{wf}}$ assumed. If it is greater than the tolerance, then return to step one (1) with the assumed $\mathrm{P}_{\mathrm{wf}}=$ calculated $\mathrm{P}_{\mathrm{wf}}$.

14. Calculate pressure loss in the tubing $\left(\Delta \mathrm{P}_{\text {tubing }}\right)$ using $\mathrm{P}_{\mathrm{wf}}-\mathrm{P}_{\mathrm{tf}}$.

The following are step by step for calculating the pressure loss in the tubing using the Sukkar and Cornel Method (applies only to vertical wells):

1. Calculate the log average temperature $(\overline{\mathrm{T}}),{ }^{\circ} \mathrm{R}$, where $\bar{T}=\frac{T_{w f}-T_{t f}}{\ln _{w f} \frac{T_{t f}}{T_{t f}}}$ 
2. Calculate the pseudo critical temperature $\left(\mathrm{T}_{\mathrm{pc}}\right),{ }^{\circ} \mathrm{R}$, where $T_{p c}=170.5+307.3 \gamma_{g}$

3. Calculate pseudo reduce temperature $\left(\mathrm{T}_{\mathrm{pr}}\right)$, where $T_{p r}=\frac{\bar{T}}{T_{p c}}$

4. Calculate pseudo critical pressure $\left(\mathrm{P}_{\mathrm{pc}}\right)$, where $P_{p c}=709.6-58.7 \gamma_{g}$

5. Calculate Moody friction factor $(\overline{\mathrm{f}})$, is a function of $N_{\mathrm{Re}}$ and $\frac{\mathrm{e}}{\mathrm{D}}$. Obtained from Moody graph or using Nikuradse Correlation or Jain Correlation.

6. Calculate $\mathrm{B}$, where $B=\frac{667 \bar{f} q_{c c}^{2} \bar{T}^{2}}{D^{2} P_{p c}^{2} \cos \theta}$

7. Calculate $\left(\mathrm{P}_{\mathrm{tf}}\right)_{\mathrm{r}}$, where $\left(P_{t f}\right)_{r}=\frac{P_{t f}}{P_{p c}}$

8. By knowing the value of $\mathrm{B}, \mathrm{T}_{\mathrm{pr}}$, and $\mathrm{P}_{\mathrm{pr}}$, then determine the value of $\int_{\left(\mathrm{P}_{\mathrm{tf}}\right)_{\mathrm{r}}}^{\left(\mathrm{P}_{\mathrm{w}}\right)_{r}} \mathrm{I}\left(\mathrm{P}_{\mathrm{r}}\right) \mathrm{dP} \mathrm{P}_{\mathrm{r}}$, where $\int_{\left(P_{t f}\right)_{r}}^{\left(P_{w f}\right)_{r}} I\left(P_{r}\right) d P_{r}=\int_{0.2}^{\left(P_{w f}\right)_{r}} I\left(P_{r}\right) d P_{r}-\int_{0.2}^{\left(P_{t f}\right)_{r}} I\left(P_{r}\right) d P_{r}$

The integral value of 0.2 may be evaluated from any arbitrary lower limit.

Then $\int_{0.2}^{\left(P_{w f}\right)_{r}} I\left(P_{r}\right) d P_{r}=\int_{0.2}^{\left(P_{t f}\right)_{r}} I\left(P_{r}\right) d P_{r}+\frac{\gamma_{g} Z}{53.34 \bar{T}}$

The integral value can be found using the Sukkar and Cornel table.

9. Calculate the value of $\frac{\gamma_{g} Z}{53.34 \bar{T}}$

10. Sum up the calculated value in step nine (9) with the integral value calculated in step eight (8). The result will be the same as the right side of the equation step eight (8).

11. From the value of $T_{\mathrm{pr}}$ and the right-hand side of the equation step (8) in step (10), then using the Sukkar and Cornel table we obtain the value of $\left(\mathrm{P}_{\mathrm{wf}}\right)_{\mathrm{r}}$ (if the value does not exist, it can be interpolated).

12. Calculate the $\mathrm{P}_{\mathrm{wf}}$, psia, where $P_{w f}=\left(P_{w f}\right)_{r}\left(P_{p c}\right)$ (20)

13. Calculate pressure loss in the tubing $\left(\Delta P_{\text {tubing }}\right)$ using $P_{w f}-P_{t f}$

The following are step by step for calculating the pressure loss in the tubing using the Cullender and Smith Method:

1. Calculate the midpoint temperature value $\left(\mathrm{T}_{\mathrm{mf}}\right),{ }^{\circ} \mathrm{R}$, where $T_{m f}=\frac{T_{t f}+T_{w f}}{2}$

2. Calculate the pseudo critical temperature $\left(\mathrm{T}_{\mathrm{pc}}\right),{ }^{\circ} \mathrm{R}$, where $T_{p c}=170.5+307.3 \gamma_{g}$

3. Calculate $\mathrm{T}_{\mathrm{pr}}$ at well head, midpoint, and bottom hole using equation:

Well head: $T_{p r}=\frac{T_{t f}}{T_{p c}} \quad$ (24)

Midpoint: $T_{p r}=\frac{T_{m f}}{T_{p c}}$

Bottom hole: $T_{p r}=\frac{T_{w f}}{T_{p c}}$

4. Calculate pseudo critical pressure $\left(\mathrm{P}_{\mathrm{pc}}\right)$ use Equation (14)

5. Calculate $\mathrm{P}_{\mathrm{pr}}$ at well head, where $P_{p r}=\frac{P_{t f}}{P_{p c}}$

6. Calculate $\mathrm{F}$ using equation $F=\frac{0.10796 q_{s c}}{D^{2.612}}$ for $D<4.227$ in and $F=\frac{0.10337 q_{s c}}{D^{2.582}}$ for $D>4.227$ in

Or it can be obtained using Cullender and Smith table.

7. Calculate $\mathrm{z}$ factor at well head $\left(\mathrm{z}_{\mathrm{tf}}\right)$, as a function of $\mathrm{P}_{\mathrm{pr}}$ and $\mathrm{T}_{\mathrm{pr}}$ from gas deviation factor for natural gases (z-chart) as can be seen in Figure 2.

8. Calculate length of tubing (L), ft.

9. Calculate $\mathrm{I}_{\mathrm{tf}}$ at well head conditions, where $I_{t f}=\frac{\frac{P}{T z}}{F^{2}+\frac{1}{1000} \frac{z}{L}\left(\frac{P}{T z}\right)^{2}}$ and $F^{2}=\frac{2.665(f / 4) q_{s c}^{2}}{D^{5}}$

10. Assume $\mathrm{I}_{\mathrm{mf}}=\mathrm{I}_{\mathrm{ff}}$ for the conditions at the average well depth or at the midpoint of the flow string or tubing.

11. Calculate $\mathrm{P}_{\mathrm{mf}}$, where $37.5 \gamma_{g} \frac{z}{2}=\left(P_{m f}-P_{t f}\right)\left(I_{m f}+I_{t f}\right)$

12. Calculate $\mathrm{P}_{\mathrm{pr}}$ at midpoint using equation $P_{p r}=\frac{P_{m f}}{P_{p c}}$ 
13. Calculate $\mathrm{z}$ factor at midpoint $\left(\mathrm{z}_{\mathrm{mf}}\right)$, as a function of $\mathrm{P}_{\mathrm{pr}}$ and $\mathrm{T}_{\mathrm{pr}}$ from $\mathrm{z}$-chart.

14. Calculate $I$ at midpoint $\left(\mathrm{I}_{\mathrm{mf}}\right)$ with the same equation in step nine (9).

15. Calculate $P_{m f}$ with the equation step (11) using the $I_{m f}$ calculated in step fourteen (14).

16. Comparing the assumed $\mathrm{P}_{\mathrm{mf}}$ with the calculated $\mathrm{P}_{\mathrm{mf}}$. If the difference is greater than 1 psi, then the calculation returns to step twelve (12) with the assumed $\mathrm{P}_{\mathrm{mf}}=$ calculated $\mathrm{P}_{\mathrm{mf}}$. If the difference is less than $1 \mathrm{psi}$, then $\mathrm{P}_{\mathrm{mf}}=\mathrm{P}_{\mathrm{mf}}$ assumption.

17. Assume $\mathrm{I}_{\mathrm{wf}}=\mathrm{I}_{\mathrm{mf}}$ for the conditions at the bottom of the flow string or tubing.

18. Calculate $\mathrm{P}_{\mathrm{wf}}$ for the bottom of the flow string or tubing, where $37.5 \gamma_{g} \frac{z}{2}=\left(P_{w f}-P_{m f}\right)\left(I_{w f}+I_{m f}\right)$

19. Calculate $\mathrm{P}_{\mathrm{pr}}$ at the bottom of the flow string or tubing where $P_{p r}=\frac{P_{w f}}{P_{p c}}$

20. Calculate $\mathrm{z}$ factor at the bottom of the flow string or tubing $\left(\mathrm{z}_{\mathrm{wf}}\right)$, as a function of $\mathrm{P}_{\mathrm{pr}}$ and $\mathrm{T}_{\mathrm{pr}}$ from $\mathrm{z}$-chart on Figure 2.

21. Calculate $I$ at the bottom of the flow string or tubing $\left(\mathrm{I}_{\mathrm{wf}}\right)$ with the same equation in step nine (9).

22. Calculate $P_{w f}$ using the same equation in step eighteen (18).

23. Comparing the assumed $P_{w f}$ with the calculated $P_{w f}$. If the difference is greater than 1 psi, then the calculation returns to step nineteen (19) with the assumed $\mathrm{P}_{\mathrm{wf}}=$ calculated $\mathrm{P}_{\mathrm{wf}}$. If the difference is less than 1 psi, then $\mathrm{P}_{\mathrm{wf}}=\mathrm{P}_{\mathrm{wf}}$ assumption.

24. Calculate pressure loss in the tubing $\left(\Delta \mathrm{P}_{\text {tubing }}\right)$ using $\mathrm{P}_{\mathrm{wf}}-\mathrm{P}_{\mathrm{tf}}$. 


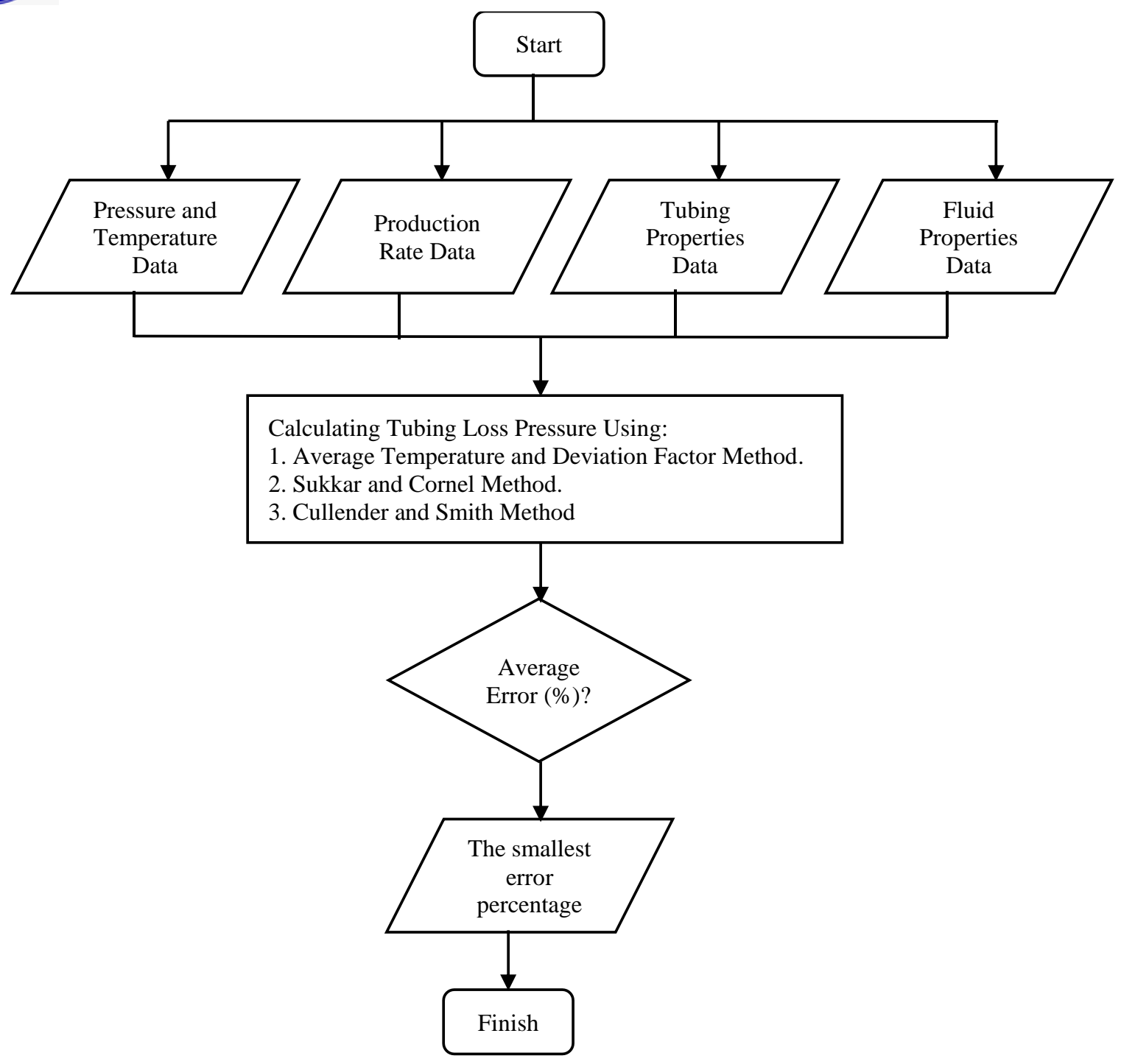

Figure 1. Flowchart Validation Tubing Loss Pressure 


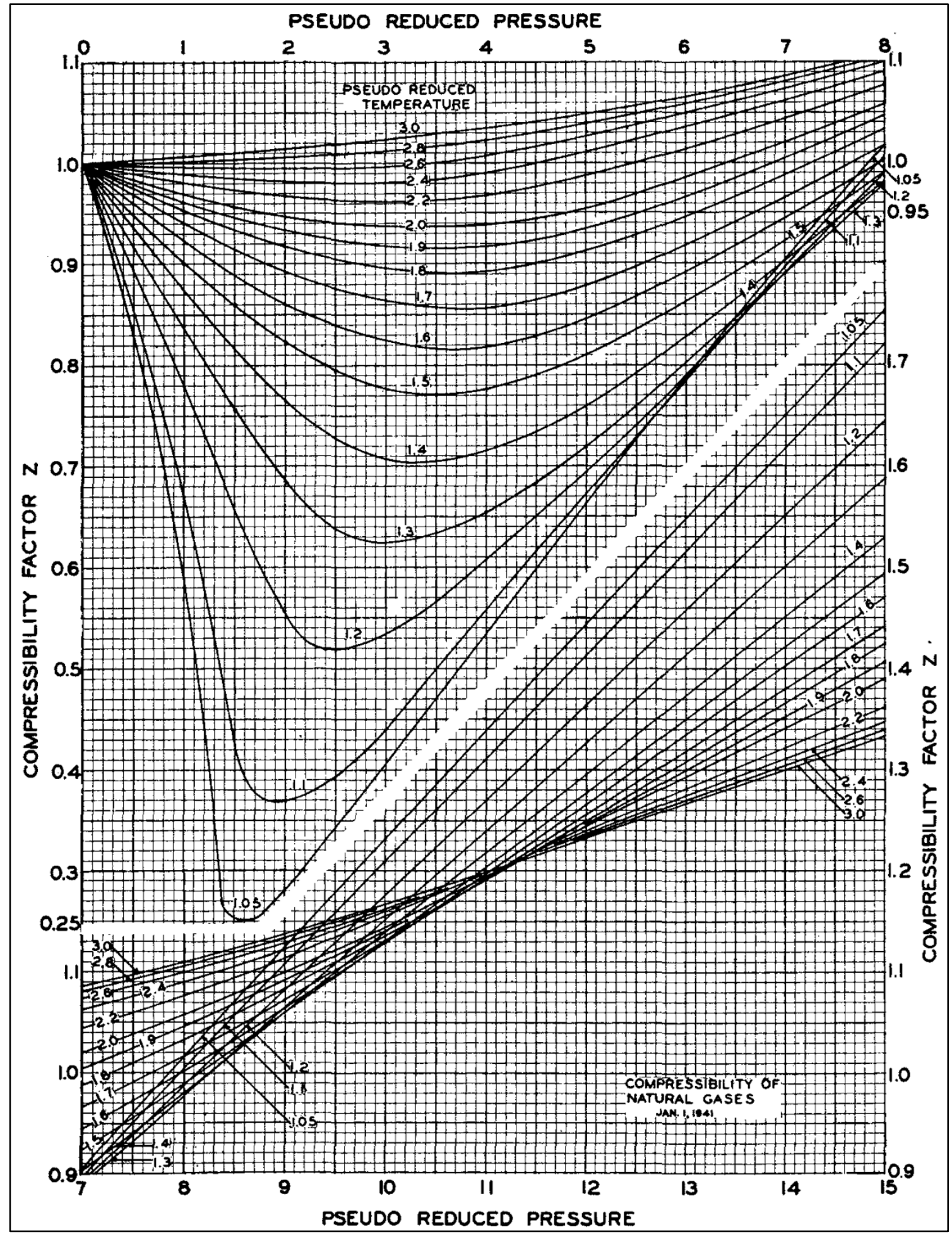

Figure 2. Compressibility Factor

(M. B. Standing and D. L. Katz, 1942)

III. RESULTS AND DISCUSSION 
The data used in calculating the pressure loss in the tubing is taken from 7 (seven) gas production wells in the $M Z$ Field in East Kalimantan area. The gas production wells used are Z-01, Z-02, Z-03, Z-04, Z-05, Z-06, and Z-07. We can see the data for each well in the MZ Field in Table 1 below. While the field data needed in the analysis of the calculation of the pressure loss in the tubing are:

1. Flowing well head pressure $\left(\mathrm{P}_{\mathrm{tf}}\right)$, psia.

2. Flowing well head temperature $\left(\mathrm{T}_{\mathrm{tf}}\right),{ }^{\circ} \mathrm{R}$.

3. Flowing bottom hole temperature $\left(\mathrm{T}_{\mathrm{wf}}\right),{ }^{\circ} \mathrm{R}$.

4. Specific gravity of gas $\left(\gamma_{\mathrm{g}}\right)$.

5. Gas flow rate $\left(\mathrm{qg}_{\mathrm{g}}\right)$, MMscfd at $14.65 \mathrm{psia}$ and $60^{\circ} \mathrm{F}$.

6. Length of flow string $(\mathrm{L})$, ft.

7. Angle of well from vertical $(\theta)$, degree.

8. Inside diameter of tubing (I.D), inch.

9. Pipe absolute roughness (e), inch.

Table 1. MZ Field Gas Well Data

\begin{tabular}{ccccccccc}
\hline $\begin{array}{c}\text { Well } \\
\text { Name }\end{array}$ & $\begin{array}{c}\mathbf{q g}, \\
\text { MMscfd }\end{array}$ & $\begin{array}{c}\text { I.D tubing, } \\
\text { in }\end{array}$ & $\begin{array}{c}\text { SG of } \\
\text { gas }\end{array}$ & $\begin{array}{c}\mathbf{L} \\
\text { tubing, } \\
\mathbf{f t}\end{array}$ & $\begin{array}{c}\mathbf{P}_{\mathbf{w f}} \\
\text { (measured), } \\
\mathbf{p s i a}\end{array}$ & $\begin{array}{c}\mathbf{P}_{\mathbf{t f}}, \\
\mathbf{p s i a}\end{array}$ & $\begin{array}{c}\mathbf{T}_{\mathbf{w f}}, \\
{ }^{\circ} \mathbf{F}\end{array}$ & $\begin{array}{c}\mathbf{T}_{\text {tf, }} \\
{ }^{\circ} \mathbf{F}\end{array}$ \\
\hline Z-01 & 4.20 & 1.995 & 0.746 & 13904 & 2170 & 1345 & 278 & 121 \\
\hline Z-02 & 7.75 & 2.992 & 0.718 & 10730 & 2518 & 1812 & 207 & 110 \\
\hline Z-03 & 3.11 & 1.995 & 0.755 & 11682 & 1942 & 1383 & 240 & 121 \\
\hline Z-04 & 12.85 & 2.992 & 0.7 & 12464 & 3114 & 2235 & 257 & 128 \\
\hline Z-05 & 3.50 & 1.995 & 0.7 & 12523 & 1838 & 1240 & 246 & 128 \\
\hline Z-06 & 2.61 & 2.992 & 0.78 & 12716 & 2061 & 1455 & 260 & 121 \\
\hline Z-07 & 2.91 & 2.992 & 0.693 & 12854 & 2347 & 1786 & 276 & 121 \\
\hline
\end{tabular}

An example of calculating the pressure loss in the tubing in this study is using the Cullender and Smith Method. An example of the calculation of pressure loss is carried out at Well Z-01 and then the results will be compared with the results of calculations with other methods we can see in Table 2 . The calculation of the pressure loss in the tubing using the Cullender and Smith Method at Well Z-01 is first carried out by calculating the well flowing bottom hole pressure $\left(\mathrm{P}_{\mathrm{wf}}\right)$, where the difference between the well flowing bottom hole pressure $\left(\mathrm{P}_{\mathrm{wf}}\right)$ and the flowing well head pressure $\left(\mathrm{P}_{\mathrm{tf}}\right)$ is the calculated pressure loss in the tubing.

By calculating the pressure loss in the tubing with these three methods, then comparing the measured pressure loss in the actual tubing conditions so that the percent error between calculations and measurements is obtained. The measured pressure loss in the tubing is the differences between the flowing bottom hole pressure measured in field conditions and the measured at the flowing well head pressure.

The following is an example results of the calculation of pressure loss in the tubing using the Cullender and Smith Method from the Z-01 Well data:

1. Calculate $\mathrm{T}_{\mathrm{mf}}$.

$$
\mathrm{T}_{\mathrm{mf}}=\frac{\mathrm{T}_{\mathrm{tf}}+\mathrm{T}_{\mathrm{wf}}}{2}=\frac{(581+738)^{\circ} \mathrm{R}}{2}=659.5^{\circ} \mathrm{R}
$$

2. Calculate $\mathrm{T}_{\mathrm{pc}}$.

$$
\mathrm{T}_{\mathrm{pc}}=170.5+307.3 \gamma_{\mathrm{g}}=170.5+307.3(0.746)=399.75^{\circ} \mathrm{R}
$$

3. Calculate $\mathrm{T}_{\mathrm{pr}}$. At well head:

$$
\mathrm{T}_{\mathrm{pr}}=\frac{\mathrm{T}_{\mathrm{tf}}}{\mathrm{T}_{\mathrm{pc}}}=\frac{581^{\circ} \mathrm{R}}{399.75^{\circ} \mathrm{R}}=1.45
$$

At midpoint: 


$$
\mathrm{T}_{\mathrm{pr}}=\frac{\mathrm{T}_{\mathrm{mf}}}{\mathrm{T}_{\mathrm{pc}}}=\frac{659.5^{\circ} \mathrm{R}}{399.75^{\circ} \mathrm{R}}=1.65
$$

At bottom hole:

$$
\mathrm{T}_{\mathrm{pr}}=\frac{\mathrm{T}_{\mathrm{wf}}}{\mathrm{T}_{\mathrm{pc}}}=\frac{738^{\circ} \mathrm{R}}{399.75^{\circ} \mathrm{R}}=1.85
$$

4. Calculate $\mathrm{P}_{\mathrm{pc}}$.

$$
P_{p c}=709.6-58.7 \gamma_{g}=709.6-58.7(0.746)=665.81
$$

5. Calculate $\mathrm{P}_{\mathrm{pr}}$ at well head.

$$
\mathrm{P}_{\mathrm{pr}}=\frac{\mathrm{P}_{\mathrm{tf}}}{\mathrm{P}_{\mathrm{pc}}}=\frac{1345}{665.81}=2.02
$$

6. $\mathrm{D}=1.995 \mathrm{in}<4.277 \mathrm{in}$.

$$
\begin{gathered}
\mathrm{F}=\frac{0.10796 \mathrm{q}_{\mathrm{sc}}}{\mathrm{D}^{2.612}}=\frac{0.10796(4.2)}{1.995^{2.612}}=0.0746 \\
\mathrm{~F}^{2}=5.573 \times 10^{-3}
\end{gathered}
$$

7. From $\mathrm{T}_{\mathrm{pr}}=1.45$ at well head and $\mathrm{P}_{\mathrm{pr}}=2.02$, determine $\mathrm{z}_{\mathrm{tf}}$ from gas deviation factor chart ( $\mathrm{z}$-chart). $\mathrm{z}_{\mathrm{tf}}=$ 0.80 .

8. Calculate L. $\mathrm{L}=13904 \mathrm{ft}$.

9. Calculate $\mathrm{I}_{\mathrm{ff}}$ at well head.

$$
\begin{gathered}
\mathrm{I}_{\mathrm{tf}}=\frac{\frac{\mathrm{P}_{\mathrm{tf}}}{\mathrm{T}_{\mathrm{tf}}\left(\mathrm{z}_{\mathrm{tf}}\right)}}{\mathrm{F}^{2}+\frac{1}{1000} \frac{\mathrm{z}}{\mathrm{L}}\left(\frac{\mathrm{P}_{\mathrm{tf}}}{\mathrm{T}_{\mathrm{tf}}\left(\mathrm{z}_{\mathrm{tf}}\right)}\right)^{2}}=\frac{\frac{1345}{581(0.80)}}{5.573 \times 10^{-3}+\frac{1}{1000} \frac{13904}{13904}\left(\frac{1345}{581(0.80)}\right)^{2}} \\
\mathrm{I}_{\mathrm{tf}}=207.44
\end{gathered}
$$

10. Assume $\mathrm{I}_{\mathrm{mf}}=\mathrm{I}_{\mathrm{ff}}=207.44$.

11. Calculate $\mathrm{P}_{\mathrm{mf}}$.

$$
\begin{aligned}
37.5 \gamma_{\mathrm{g}} \frac{\mathrm{z}}{2} & =\left(\mathrm{P}_{\mathrm{mf}}-\mathrm{P}_{\mathrm{tf}}\right)\left(\mathrm{I}_{\mathrm{mf}}+\mathrm{I}_{\mathrm{tf}}\right) \\
37.5(0.746) \frac{13904}{2} & =\left(\mathrm{P}_{\mathrm{mf}}-1345\right)(207.44+207.44) \\
\mathrm{P}_{\mathrm{mf}} & =1813.77 \text { psia }
\end{aligned}
$$

12. Calculate $\mathrm{P}_{\mathrm{pr}}$ at midpoint.

$$
\mathrm{P}_{\mathrm{pr}}=\frac{\mathrm{P}_{\mathrm{mf}}}{\mathrm{P}_{\mathrm{pc}}}=\frac{1813.77}{665.81}=2.72
$$

13. From $\mathrm{T}_{\mathrm{pr}}=1.65$ at midpoint and $\mathrm{P}_{\mathrm{pr}}=2.72$, determine $\mathrm{z}_{\mathrm{mf}}$ from gas deviation factor chart ( $\mathrm{z}$-chart). $\mathrm{z}_{\mathrm{mf}}=$ 0.86 .

14. Calculate $\mathrm{I}_{\mathrm{mf}}$ at midpoint. 


$$
\begin{gathered}
\mathrm{I}_{\mathrm{mf}}=\frac{\frac{\mathrm{P}_{\mathrm{mf}}}{\mathrm{T}_{\mathrm{mf}}\left(\mathrm{z}_{\mathrm{mf}}\right)}}{\mathrm{F}^{2}+\frac{1}{1000} \frac{\mathrm{z}}{\mathrm{L}}\left(\frac{\mathrm{P}_{\mathrm{mf}}}{\mathrm{T}_{\mathrm{mf}}\left(\mathrm{z}_{\mathrm{mf}}\right)}\right)^{2}}=\frac{\frac{1813.77}{659.5(0.86)}}{5.573 \times 10^{-3}+\frac{1}{1000} \frac{13904}{13904}\left(\frac{1813.77}{659.5(0.86)}\right)^{2}} \\
\mathrm{I}_{\mathrm{mf}}=202.36
\end{gathered}
$$

15. Calculate $\mathrm{P}_{\mathrm{mf}}$.

$$
\begin{aligned}
37.5 \gamma_{\mathrm{g}} \frac{\mathrm{z}}{2} & =\left(\mathrm{P}_{\mathrm{mf}}-\mathrm{P}_{\mathrm{tf}}\right)\left(\mathrm{I}_{\mathrm{mf}}+\mathrm{I}_{\mathrm{tf}}\right) \\
37.5(0.746) \frac{13904}{2} & =\left(\mathrm{P}_{\mathrm{mf}}-1345\right)(202.36+207.44) \\
\mathrm{P}_{\mathrm{mf}} & =1819.58 \text { psia }
\end{aligned}
$$

16. Comparing the assumed $\mathrm{P}_{\mathrm{mf}}$ with the calculated $\mathrm{P}_{\mathrm{mf}}$. The difference is greater than 1 psi, then the calculation returns to step (12).

Calculate $\mathrm{P}_{\mathrm{pr}}$ at midpoint.

$$
\mathrm{P}_{\mathrm{pr}}=\frac{\mathrm{P}_{\mathrm{mf}}}{\mathrm{P}_{\mathrm{pc}}}=\frac{1819.58}{665.81}=2.73
$$

From $\mathrm{T}_{\mathrm{pr}}=1.65$ at midpoint and $\mathrm{P}_{\mathrm{pr}}=2.73$, determine $\mathrm{z}_{\mathrm{mf}}$ from gas deviation factor chart (z-chart). $\mathrm{z}_{\mathrm{mf}}=$ 0.86 .

Calculate $\mathrm{I}_{\mathrm{mf}}$ at midpoint.

$$
\begin{gathered}
\mathrm{I}_{\mathrm{mf}}=\frac{\frac{\mathrm{P}_{\mathrm{mf}}}{\mathrm{T}_{\mathrm{mf}}\left(\mathrm{z}_{\mathrm{mf}}\right)}}{\mathrm{F}^{2}+\frac{1}{1000} \frac{\mathrm{Z}}{\mathrm{L}}\left(\frac{\mathrm{P}_{\mathrm{mf}}}{\mathrm{T}_{\mathrm{mf}}\left(\mathrm{z}_{\mathrm{mf}}\right)}\right)^{2}} \\
\mathrm{I}_{\mathrm{mf}}=\frac{\frac{1819.58}{659.5(0.86)}}{5.573 \times 10^{-3}+\frac{1}{1000} \frac{13904}{13904}\left(\frac{1819.58}{659.5(0.86)}\right)^{2}} \\
\mathrm{I}_{\mathrm{mf}}=202.17
\end{gathered}
$$

Calculate $\mathrm{P}_{\mathrm{mf}}$.

$$
\begin{aligned}
37.5 \gamma_{\mathrm{g}} \frac{\mathrm{z}}{2} & =\left(\mathrm{P}_{\mathrm{mf}}-\mathrm{P}_{\mathrm{tf}}\right)\left(\mathrm{I}_{\mathrm{mf}}+\mathrm{I}_{\mathrm{tf}}\right) \\
37.5(0.746) \frac{13904}{2} & =\left(\mathrm{P}_{\mathrm{mf}}-1345\right)(202.17+207.44) \\
\mathrm{P}_{\mathrm{mf}} & =1819.80 \text { psia }
\end{aligned}
$$

17. Assume $\mathrm{I}_{\mathrm{wf}}=\mathrm{I}_{\mathrm{mf}}=202.17$.

18. Calculate $\mathrm{P}_{\mathrm{wf}}$.

$$
\begin{gathered}
37.5 \gamma_{\mathrm{g}} \frac{\mathrm{z}}{2}=\left(\mathrm{P}_{\mathrm{wf}}-\mathrm{P}_{\mathrm{mf}}\right)\left(\mathrm{I}_{\mathrm{wf}}+\mathrm{I}_{\mathrm{mf}}\right) \\
37.5(0.746) \frac{13904}{2}=\left(\mathrm{P}_{\mathrm{wf}}-1819.80\right)(202.17+202.17)
\end{gathered}
$$




$$
\mathrm{P}_{\mathrm{wf}}=2300.78 \mathrm{psia}
$$

19. Calculate $\mathrm{P}_{\mathrm{pr}}$ at bottom hole.

$$
\mathrm{P}_{\mathrm{pr}}=\frac{\mathrm{P}_{\mathrm{wf}}}{\mathrm{P}_{\mathrm{pc}}}=\frac{2300.78}{665.81}=3.45
$$

20. From $\mathrm{T}_{\mathrm{pr}}=1.85$ at bottom hole and $\mathrm{P}_{\mathrm{pr}}=3.45$, determine $\mathrm{Z}_{\mathrm{wr}}$ from gas deviation factor chart ( $\mathrm{z}$-chart). $\mathrm{z}_{\mathrm{wf}}=0.90$.

21. Calculate $\mathrm{I}_{\mathrm{wf}}$.

$$
\begin{gathered}
\mathrm{I}_{\mathrm{wf}}=\frac{\frac{\mathrm{P}_{\mathrm{wf}}}{\mathrm{T}_{\mathrm{wf}}\left(\mathrm{z}_{\mathrm{wf}}\right)}}{\mathrm{F}^{2}+\frac{1}{1000} \frac{\mathrm{z}}{\mathrm{L}}\left(\frac{\mathrm{P}_{\mathrm{wf}}}{\mathrm{T}_{\mathrm{wf}}\left(\mathrm{z}_{\mathrm{wf}}\right)}\right)^{2}}=\frac{\frac{2300.78}{738(0.90)}}{5.573 \times 10^{-3}+\frac{1}{1000} \frac{13904}{13904}\left(\frac{2300.78}{738(0.90)}\right)^{2}} \\
\mathrm{I}_{\mathrm{wf}}=188.15
\end{gathered}
$$

22. Calculate $\mathrm{P}_{\mathrm{wf}}$.

$$
\begin{gathered}
37.5 \gamma_{\mathrm{g}} \frac{\mathrm{z}}{2}=\left(\mathrm{P}_{\mathrm{wf}}-\mathrm{P}_{\mathrm{mf}}\right)\left(\mathrm{I}_{\mathrm{wf}}+\mathrm{I}_{\mathrm{mf}}\right) \\
37.5(0.746) \frac{13904}{2}=\left(\mathrm{P}_{\mathrm{wf}}-1819.80\right)(188.15+202.17) \\
\mathrm{P}_{\mathrm{wf}}=2318.06 \text { psia }
\end{gathered}
$$

23. Comparing the assumed $\mathrm{P}_{\mathrm{wf}}$ with the calculated $\mathrm{P}_{\mathrm{wf}}$. The difference is greater than $1 \mathrm{psi}$, then the calculation returns to step (16).

Calculate $\mathrm{P}_{\mathrm{pr}}$ at bottom hole.

$$
\mathrm{P}_{\mathrm{pr}}=\frac{\mathrm{P}_{\mathrm{wf}}}{\mathrm{P}_{\mathrm{pc}}}=\frac{2318.06}{665.81}=3.48
$$

From $\mathrm{T}_{\mathrm{pr}}=1.85$ at bottom hole and $\mathrm{P}_{\mathrm{pr}}=3.48$, determine $\mathrm{z}_{\mathrm{wf}}$ from gas deviation factor chart ( $\mathrm{z}$-chart). $\mathrm{Z}_{\mathrm{wf}}=0.89$.

Calculate $\mathrm{I}_{\mathrm{wf}}$.

$$
\begin{gathered}
I_{w f}=\frac{\frac{P_{w f}}{T_{w f}\left(z_{w f}\right)}}{F^{2}+\frac{1}{1000} \frac{\mathrm{Z}}{L}\left(\frac{P_{w f}}{T_{w f}\left(z_{w f}\right)}\right)^{2}}=\frac{\frac{2318.06}{738(0.89)}}{5.573 \times 10^{-3}+\frac{1}{1000} \frac{13904}{13904}\left(\frac{2318.06}{738(0.89)}\right)^{2}} \\
I_{w f}=187.2
\end{gathered}
$$

Calculate $\mathrm{P}_{\mathrm{wf}}$.

$$
\begin{gathered}
37.5 \gamma_{\mathrm{g}} \frac{\mathrm{z}}{2}=\left(\mathrm{P}_{\mathrm{wf}}-\mathrm{P}_{\mathrm{mf}}\right)\left(\mathrm{I}_{\mathrm{wf}}+\mathrm{I}_{\mathrm{mf}}\right) \\
37.5(0.746) \frac{13904}{2}=\left(\mathrm{P}_{\mathrm{wf}}-1819.80\right)(187.2+202.17) \\
\mathrm{P}_{\mathrm{wf}}=2319.28 \mathrm{psia}
\end{gathered}
$$

24. Calculate $\Delta \mathrm{P}_{\text {tubing. }}$.

$$
\Delta \mathrm{P}_{\text {tubing }}=\mathrm{P}_{\mathrm{wf}}-\mathrm{P}_{\mathrm{tf}}=2318-1345=973 \text { psia }
$$

The same calculation conducted on other wells which can be seen at Table 2 below. 
Table 2. Calculation Result on All Wells

\begin{tabular}{|c|c|c|c|c|c|c|c|c|c|c|c|c|}
\hline \multirow[b]{2}{*}{$\begin{array}{c}\text { Well } \\
\text { Name }\end{array}$} & \multirow[b]{2}{*}{$\begin{array}{c}\text { Pwf } \\
\text { measured } \\
(\text { psia })\end{array}$} & \multirow[b]{2}{*}{$\begin{array}{c}\text { Ptf } \\
\text { (psia) }\end{array}$} & \multicolumn{3}{|c|}{ Pwf calculated } & \multirow[b]{2}{*}{$\begin{array}{c}\text { Pressure } \\
\text { Loss } \\
\text { measured } \\
(\text { psia })\end{array}$} & \multicolumn{3}{|c|}{ Pressure Loss calculated (psia) } & \multicolumn{3}{|c|}{ Error (percent) } \\
\hline & & & $\begin{array}{l}\text { Average } \\
\text { Temp } \\
\text { and } \\
\text { Deviation } \\
\text { Factor } \\
\end{array}$ & $\begin{array}{c}\text { Sukkar } \\
\text { and } \\
\text { Cornell }\end{array}$ & $\begin{array}{l}\text { Cullender } \\
\text { and } \\
\text { Smith }\end{array}$ & & $\begin{array}{c}\text { Average } \\
\text { Temp } \\
\text { and } \\
\text { Deviation } \\
\text { Factor } \\
\end{array}$ & $\begin{array}{c}\text { Sukkar } \\
\text { and } \\
\text { Cornell }\end{array}$ & $\begin{array}{l}\text { Cullender } \\
\text { and } \\
\text { Smith }\end{array}$ & $\begin{array}{l}\text { Average } \\
\text { Temp } \\
\text { and } \\
\text { Deviation } \\
\text { Factor } \\
\end{array}$ & $\begin{array}{c}\text { Sukkar } \\
\text { and } \\
\text { Cornell }\end{array}$ & $\begin{array}{c}\text { Cullender } \\
\text { and } \\
\text { Smith }\end{array}$ \\
\hline Z-01 & 2170 & 1345 & 2322 & 2131 & 2318 & 825 & 977 & 786 & 973 & 7.00 & 1.80 & 6.82 \\
\hline Z-02 & 2518 & 1812 & 2597 & 2654 & 2507 & 706 & 785 & 842 & 695 & 3.14 & 5.40 & 0.44 \\
\hline Z-03 & 1942 & 1383 & 2106 & 2111 & 2072 & 559 & 723 & 728 & 689 & 8.43 & 8.70 & 6.69 \\
\hline Z-04 & 3114 & 2235 & 3019 & 3252 & 3243 & 879 & 784 & 1017 & 1008 & 3.05 & 4.43 & 4.14 \\
\hline Z-05 & 1838 & 1240 & 1939 & 2003 & 1925 & 598 & 699 & 763 & 685 & 5.50 & 8.98 & 4.73 \\
\hline Z-06 & 2061 & 1455 & 2100 & 1980 & 2080 & 606 & 645 & 525 & 625 & 1.91 & 3.93 & 0.92 \\
\hline Z-07 & 2347 & 1786 & 2550 & 2495 & 2419 & 561 & 764 & 555 & 633 & 8.65 & 6.31 & 3.07 \\
\hline \multicolumn{10}{|c|}{ Average error (percent) } & 5.38 & 5.65 & 3.83 \\
\hline
\end{tabular}

Pressure loss measured is a difference between $\mathrm{P}_{\mathrm{wf}}$ measured and $\mathrm{P}_{\mathrm{tf}}$. For example, pressure loss measured on Well Z-01 is:

$$
\Delta \mathrm{P}_{\text {measured }}=\left(\mathrm{P}_{\mathrm{wf}}\right)_{\text {measured }}-\mathrm{P}_{\mathrm{tf}}=2170-1345=825 \text { psia }
$$

The pressure loss measured obtained is 825 psia, where the data used is bottom hole pressure and well head pressure obtained from measurement in the well. The difference between bottom hole pressure and well head pressure obtained from each well is the measured pressure loss in the tubing $\left(\Delta \mathrm{P}_{\text {measured }}\right)$.

For the error percentage obtained from each method is the difference between $\mathrm{P}_{\mathrm{wf}}$ calculated and $\mathrm{P}_{\mathrm{wf}}$ measured compared to the $\mathrm{P}_{\mathrm{wf}}$ measured. From that calculation, will be obtained error percentage comparison from each method. For example, error percentage on Well Z-01 using Cullender and Smith Method is:

$$
\text { Error percentage }=\frac{\left(\mathrm{P}_{\mathrm{wf}}\right)_{\text {calculated }}-\left(\mathrm{P}_{\mathrm{wf}}\right)_{\text {measured }}}{\left(\mathrm{P}_{\mathrm{wf}}\right)_{\text {measured }}}=\frac{(2318-2170) \text { psia }}{2170 \mathrm{psia}}=0.0682
$$

Error percentage $=6.82 \%$

After calculating error percentage from each well using all methods, then it can be seen the average percent error of each method. While the average error percentage in one method is the sum of the percent errors of all wells in one method divided by the number of the wells. For example, average error percentage on Cullender and Smith Method is:

$$
\begin{gathered}
\text { Average error percentage }=\frac{(\text { Error percentage well } 1+\text { well } 2+\text { well } \ldots \mathrm{n})}{\text { number of wells }} \\
\text { Average error percentage }=\frac{(6.82+0.44+6.69+4.14+4.73+0.92+3.07)}{7}=3.83 \%
\end{gathered}
$$

Based on the calculation conducted from each method shown in Table 2, the Cullender and Smith Method have the lowest average error percentage compared to other methods. In this study, it can be stated that the Cullender and Smith Method is more valid than other methods to determine pressure loss in the tubing.

\section{CONCLUSION}


Based on this study, it can be concluded that:

1. The Cullender and Smith method resulting the smallest error percentage in calculating the pressure loss in the tubing with $3.83 \%$ compared to the Average Temperature and Deviation Factor Method with $5.38 \%$ and the Sukkar and Cornell Method with $5.65 \%$.

2. The Cullender and Smith method is most widely used in the field to determine the pressure loss in the tubing in gas wells, so it can be said to be valid or the most accurate method for used in the field compared to other methods due to resulting the smallest percent error from the calculation.

\section{ACKNOWLEDGEMENTS}

We would like to thank Virginia Indonesia Company for providing this data. 


\section{REFERENCES}

Beggs, H. D. (1984). Gas Operation Productions, Chapter 3, (p.49-78). Tulsa: OGCI Publications.

Beggs, H. D., and J. P. Brill. (1973). A Study of Two-Phase Flow in Inclined Pipes. Journal of Petroleum Technology, (p.607).

Brown, K. E. (1977). The Technology of Artificial Lift Methods, Volume 1. Tulsa: Penn-Well Publishing Co.

Brown, K. E. (1980). The Technology of Artificial Lift Methods, Volume 2a, 3a, and 3b. Tulsa: Penn-Well Publishing Co.

Crawford, P. B., and G. H. Fancher. (1959). Calculation of Flowing and Static Bottom-hole Pressures of Natural Gas Wells from Surface Measurements. Bulletin 72. Austin: Texas Petroleum Research Committee.

Cullender, M. H., and R. V. Smith. (1956). Practical Solution of Gas-flow Equations for Wells and Pipelines with Large Temperature Gradients, (p.207). Trans AIME.

Duns, H., and N. C. J. Ros. Vertical Flow of Gas and Liquid Mixtures in Wells. $6^{\text {th }}$ World Petroleum Congress, Frankfurt, Germany.

Hagedorn, A. R., and K. E. Brown. (1965). Experimental Study of Pressure Gradients Occurring During Continuous Two-Phase Flow in Small Diameter Vertical Conduits. Journal of Petroleum Technology, (p.475).

Ikoku, C. U. (1984). Natural Gas Production Engineering, Chapter 8, (p.310-344). Malabar: Krieger Publishing Co.

Katz, D. L., et al. (1959). Handbook of Natural Gas Engineering. New York: McGraw-Hill.

Orkiszewski, J. (1967). Predicting Two-Phase Pressure Drops in Vertical Pipes. Journal of Petroleum Technology. P.829-838.

Poettman, F. H. (1951). The Calculation of Pressure Drops in the Flow of Natural Gas Through Pipe. Trans AIME 192, p.317-326.

Standing, M. B., and D. L. Katz. (1942). Density of Natural Gases, (p.140-149). Trans AIME 146.

Sukkar, Y. K., and D. Cornell. (1955). Direct Calculation of Bottom-hole Pressure in Natural Gas Wells. Trans AIME 204.

Wichert, E., and K. Aziz. (1972). Calculation of z's for Sour Gases. Hydrocarbon Processing 51, (p.119-122).

Young, K. L. (1967). Effect of Assumptions Used to Calculate Bottom-hole pressure in Gas Wells, (p.547550). Journal of Petroleum Technology. 